\title{
Particulate matter source apportionment in Cairo: recent measurements and comparison with previous studies
}

\author{
D. H. Lowenthal · A. W. Gertler • M. W. Labib
}

Received: 26 July 2012/Revised: 8 March 2013/Accepted: 16 March 2013/Published online: 17 April 2013

(C) Islamic Azad University (IAU) 2013

\begin{abstract}
This paper presents results of an atmospheric particulate matter (PM) monitoring and source apportionment study conducted during summer and fall 2010 in Cairo. These results are compared to those of similar studies in 1999 and 2002. Concentrations of $\mathrm{PM}_{2.5}$ and $\mathrm{PM}_{10}$ mass and their chemical constituents were determined and chemical mass balance modeling was conducted to estimate the source contributions to ambient PM. Emphasis was placed on characterizing the long-term trends in atmospheric lead $(\mathrm{Pb})$ concentrations and their sources in Cairo. $\mathrm{PM}_{2.5}$ and $\mathrm{PM}_{10}$ concentrations were highest during fall 1999 at four of the five study sites. This was also the case for open (vegetative/trash) burning contributions, which showed a smaller increase during fall 2010. Burning of agricultural waste after the fall harvest continues to be a major source of PM in Cairo. Both $\mathrm{PM}_{2.5}$ and $\mathrm{PM}_{10}$ mass decreased dramatically at Shobra, an industrial site, from 1999 to 2010. A reduction of lead smelting has resulted in a decrease of ambient $\mathrm{Pb}$ concentrations of up to two orders of magnitude from 1999 to 2010 at Shobra, El-Zamalek, and El-Qualaly. From 1999 to 2010, the mobile source contribution has been relatively stable at most of the study sites. Future efforts to reduce ambient PM should focus on controlling emissions from motor vehicles and open burning and implementing
\end{abstract}

Electronic supplementary material The online version of this article (doi:10.1007/s13762-013-0272-6) contains supplementary material, which is available to authorized users.

D. H. Lowenthal $(\bowtie) \cdot$ A. W. Gertler

Desert Research Institute, Reno, NV 89512, USA

e-mail: dougl@dri.edu

M. W. Labib

Egyptian Environmental Affairs Agency, Cairo, Egypt mitigation strategies for reducing resuspended road and construction dust.

Keywords Cairo - Particulate matter - Source apportionment $\cdot$ Lead smelter

\section{Introduction}

Cairo, Egypt is classified as one of the world's "megacities", with an estimated population in excess of 20 million people in the greater Cairo area. Air quality is degraded by high concentrations of particulate matter (PM), carbon monoxide, oxides of nitrogen, ozone, and sulfur dioxide (El-Shazly et al. 1990; Hindy 1991; Nasralla 1994; Rodes et al. 1996; Sturchio et al. 1997; Abu-Allaban et al. 2002, 2007). In order to develop and implement a pollutioncontrol strategy and to reduce the health impacts of air pollution in Cairo, the US Agency for International Development (USAID) sponsored the Cairo Air Improvement Project (CAIP) (Chemonics International Inc 1997). One aspect of the CAIP includes routine monitoring of $\mathrm{PM}_{10}, \mathrm{PM}_{2.5}$ and lead $(\mathrm{Pb})$ at sites throughout the greater Cairo area. Howes et al. (2000) reported baseline year monitoring results for the CAIP. Only 37 of the $1,783 \mathrm{PM}_{10}$ measurements recorded during the study period were below the Government of Egypt $24 \mathrm{~h}$ limit of $70 \mu \mathrm{g} / \mathrm{m}^{3}$. The highest annual average $\mathrm{PM}_{10} \mathrm{~Pb}$ levels observed were $26 \mu \mathrm{g} / \mathrm{m}^{3}$ at the highly industrialized Shobra Kheima site.

As part of the CAIP, $\mathrm{PM}_{10}$ and $\mathrm{PM}_{2.5}$ monitoring and source attribution studies were conducted in Cairo during the periods of February 21 to March 3, 1999, October 29 to November 27, 1999, and June 8 to June 26, 2002 (Abu-Allaban et al. 2002, 2007). PM sampling was done at six sites: (1) Kaha (background); (2) El-Maa'sara 
(industrial/residential); (3) Shobra (El-Sahel, site 19, industrial/residential); (4) El-Qualaly (mobile sources); (5) El-Zamalek (residential); and (6) Helwan (residential). The sites are shown in Fig. 1. Source emissions samples representing soil and road dust, brick manufacturing, cast iron foundry, copper foundry, lead smelting, refuse and biomass burning, Mazot oil combustion, restaurants, and motor vehicles were also characterized. Shobra exhibited the highest daily average $\mathrm{PM}_{2.5}$ and $\mathrm{PM}_{10}$ mass concentrations, which ranged from 61 to 216 and 154 to $360 \mu \mathrm{g} / \mathrm{m}^{3}$, respectively. For comparison, annual average $\mathrm{PM}_{2.5}$ concentrations ranged from 58 to $95 \mu \mathrm{g} / \mathrm{m}^{3}$ in Shanghai from 2003 to 2005 (Chan and Yao 2008). In Mexico City, $\mathrm{PM}_{2.5}$ and $\mathrm{PM}_{10}$ mass concentrations ranged from 25 to 49 and 39 to $108 \mu \mathrm{g} / \mathrm{m}^{3}$, respectively, at six sites during February and March 1997 (Chow et al. 2002; Vega et al. 2009). Monthly average $\mathrm{PM}_{10}$ mass concentrations in Delhi ranged from 100 to $800 \mu \mathrm{g} / \mathrm{m}^{3}$ from August 2007 through October 2008 (Tiwari et al. 2012). In Cairo, the lowest values in both size fractions were observed at Helwan and Kaha. Average $\mathrm{PM}_{10} \mathrm{~Pb}$ concentrations at Shobra were 34, 12.7, and $7.2 \mu \mathrm{g} / \mathrm{m}^{3}$ during winter 1990, fall 1999, and summer 2002, respectively. Lead concentrations at Shobra and in Cairo in general were so high that they were in excess of $\mathrm{PM}_{10}$ and $\mathrm{PM}_{2.5}$ mass concentrations observed in many cities in the US. Depending on the site, the major contributors to $\mathrm{PM}_{10}$ included resuspended geological material, mobile source emissions, and open (vegetative/trash) burning. $\mathrm{PM}_{2.5}$ tended to be dominated by mobile source emissions, open (vegetative/trash) burning, and secondary species such as ammonium nitrate, ammonium sulfate, and ammonium chloride. Both $\mathrm{Pb}$ concentrations and $\mathrm{Pb}$ smelter source contributions were highest at Shobra during winter 1999 and decreased by nearly a factor of 5 by the summer of 2002. Similar trends were seen at El-Zamalek, El-Qualaly, and El-Maa'sara although the absolute levels were at least an order of magnitude lower than at Shobra.

PM monitoring and source apportionment studies were conducted in Cairo during summer and fall 2010 to establish long-term trends in air quality and source attribution. This study builds on the previous 1999 and 2002 source apportionment studies and allows for an assessment of how pollution controls have impacted the source contributions over time. It provides new data for improving and validating ongoing emissions inventory development in Cairo and provides regulatory agencies with sufficient data to support policies aimed at reducing ambient PM concentrations. Emphasis is placed on determining the sources of airborne $\mathrm{Pb}$ and $\mathrm{PM}$ in greater Cairo and the effectiveness of control strategies on ambient $\mathrm{Pb}$ concentrations. These studies allow for evaluation of long-term efforts to improve air quality in a highly polluted urban area.

\section{Experimental methods}

\section{Sampling sites}

Five of the six previous sites were chosen for the current study (Fig. 1). Kaha (background) is a Nile delta site with significant agricultural activity. During most of the year, the prevailing winds come from this direction. Shobra (industrial/residential) is located in a heavily industrialized area which had been downwind of numerous $\mathrm{Pb}$ smelters and other industrial sources. Since the earlier studies, many of these facilities were relocated outside of the city. El-Qualaly Square (mobile sources) is located in downtown Cairo with high exposure to light- and heavy-duty (bus) traffic. El-Zamalek and Helwan are residential locations. El-Zamalek is located on an island in the Nile River and is a residential area with limited nearby sources. Helwan is impacted by emissions from motor vehicles and nearby cement plants and has higher PM levels than at El-Zamalek.

\section{Ambient measurements}

Ambient $\mathrm{PM}_{2.5}$ and $\mathrm{PM}_{10}$ samples were collected every second day at the five sites from May 28 to June 21, 2010 (summer) and October 10 to 30, 2010 (fall). All samples were of $24 \mathrm{~h}$ duration. Two $\mathrm{PM}_{10}$ and two $\mathrm{PM}_{2.5}$ lowvolume Airmetric Minivol samplers with flow rates of approximately $5 \mathrm{~L} / \mathrm{min}$ were deployed at each location. For each size cut, one sampler was loaded with a $47 \mathrm{~mm}$ Teflon membrane filter (PallFlex R2PJ047) and the other with a $47 \mathrm{~mm}$ quartz-fiber filter (Pallflex 2500QAT-UP) (Pall Corporation, Ann Arbor, MI, USA). Fifty-six summer and 55 fall $\mathrm{PM}_{2.5}$ and $\mathrm{PM}_{10}$ sample pairs were subjected to detailed chemical analysis.

\section{Laboratory analysis}

Following collection, the samples were shipped to the Desert Research Institute (DRI) in Reno, NV for chemical analysis. $\mathrm{PM}_{2.5}$ and $\mathrm{PM}_{10}$ mass on the Teflon filters was determined gravimetrically on a Cahn C-31 microbalance. Filters were equilibrated at low relative humidity $(<30 \%)$ before weighing to avoid water uptake by hygroscopic species on the filter. Elemental (Al, Si, P, S, Cl, K, Ca, Ti, $\mathrm{V}, \mathrm{Cr}, \mathrm{Mn}, \mathrm{Fe}, \mathrm{Ni}, \mathrm{Cu}, \mathrm{Zn}, \mathrm{Se}, \mathrm{Br}, \mathrm{Rb}, \mathrm{Sr}, \mathrm{Sn}, \mathrm{Sb}, \mathrm{Ba}$, and $\mathrm{Pb}$ ) concentrations on the Teflon filter were measured with X-ray fluorescence (XRF) on a Kevex 0700/8000 XRF analyzer. The quartz filters were extracted in water and sulfate $\left(\mathrm{SO}_{4}{ }^{2-}\right)$, nitrate $\left(\mathrm{NO}_{3}{ }^{-}\right)$, and chloride $\left(\mathrm{Cl}^{-}\right)$ions in the water extracts were determined by ion chromatography (IC) on a Dionex ICS 3000 ion chromatograph with a Dionex AS14 column. Soluble sodium $\left(\mathrm{Na}^{+}\right)$and 
Fig. 1 Location of ambient PM monitoring sites during the CAIP study

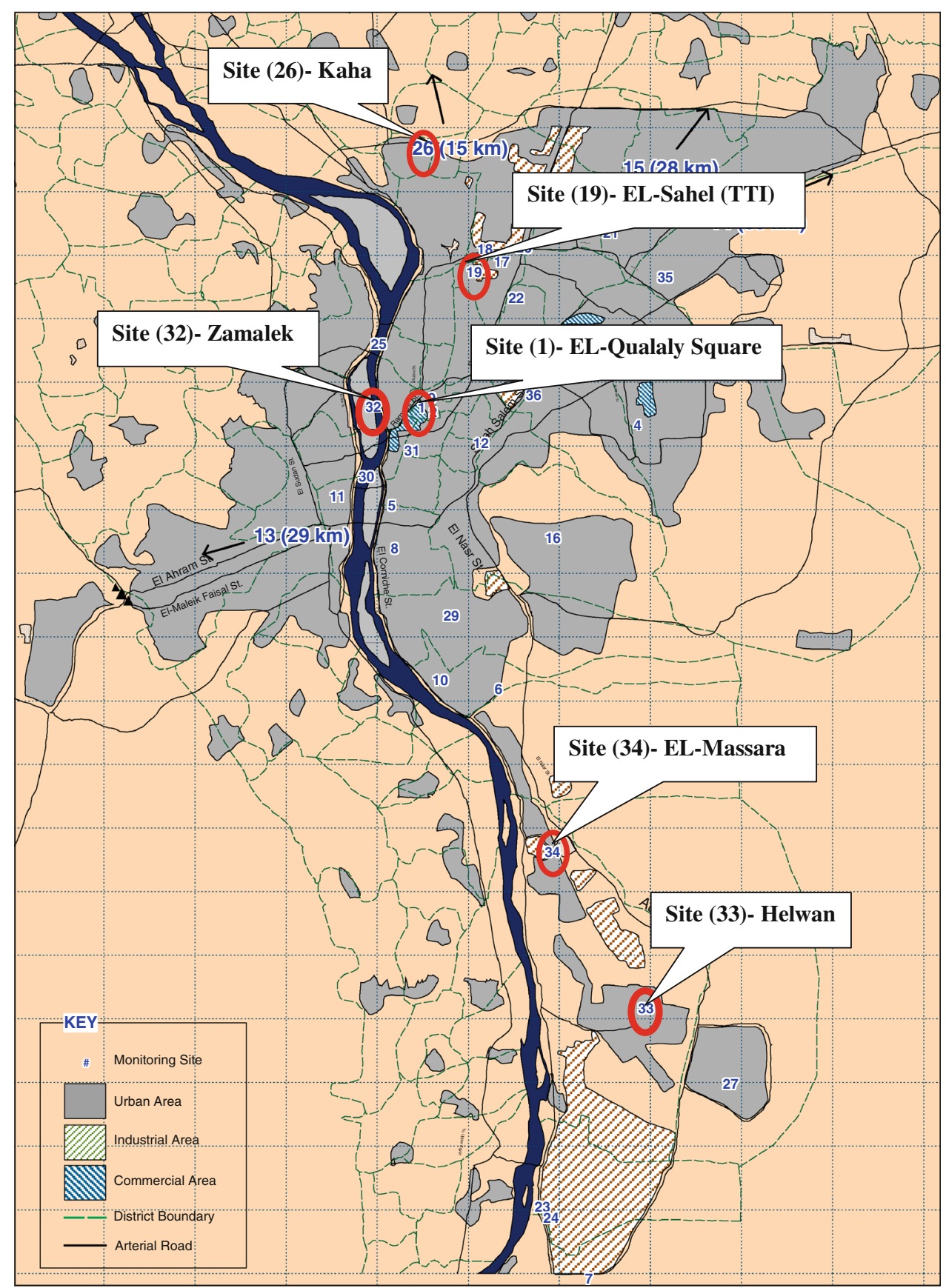

potassium $\left(\mathrm{K}^{+}\right)$were determined by atomic absorption (AA) spectroscopy on a Varian SpectraAA-880. Ammonium $\left(\mathrm{NH}_{4}{ }^{+}\right)$was determined by automated colorimetry (AC) on an Astoria Pacific Astoria Analyzer using the indophenol blue method. Bulk organic and elemental carbon (OC and EC) on the quartz filters were determined by thermal/optical reflectance (TOR) (Chow et al. 1993).

Source apportionment modeling

The chemical mass balance (CMB) receptor model was used to apportion PM and its chemical constituents to their sources (Watson et al. 1984). The CMB consists of a set of linear equations which express the ambient concentrations of chemical species as the sum of the products of the source contributions $\left(\mu \mathrm{g} / \mathrm{m}^{3}\right)$ and the source composition profiles. Source profiles are the fractions of emitted PM mass for each chemical species. The current CMB software (EPA version 8.2 http://www.epa.gov/scram001/receptor_cmb. htm) applies the effective variance least-squares solution developed and tested by Watson et al. (1984) to solve these equations.

Source characterization was conducted during the CAIP study (Abu-Allaban et al. 2007). Road dust and soil 
samples were collected at each ambient sampling site. The samples were resuspended and collected in the $\mathrm{PM}_{2.5}$ and $\mathrm{PM}_{10}$ size fractions in a laboratory chamber (Chow et al. 1994). Stack samples were collected at a lead smelter, a copper foundry, a cement plant, a scrap iron foundry, and at a Mazot oil power plant. Samples were collected just downwind of open burning. Motor vehicle emissions were sampled in a tunnel near the Sheraton Hotel in Cairo and thus represented a mixture of emissions from spark ignition (gasoline) and diesel vehicles travelling through the tunnel. The source profiles used in the Cairo CMB modeling are described in Table 1. The $\mathrm{PM}_{2.5}$ and $\mathrm{PM}_{10}$ source profiles are presented in Tables $1 \mathrm{~S}$ and $2 \mathrm{~S}$, respectively, in the supplementary material. These profiles were compiled from previous CAIP and other studies. Tests were done to determine which profiles best explained the ambient concentrations. Geological (e.g., paved and unpaved road dust, desert soil) CAIP profiles were used in all cases. It was not possible to distinguish gasoline from diesel vehicles because the available profiles were too similar (collinear).

The CAIP copper foundry and lead smelter profiles were needed to account for $\mathrm{Zn}$ and $\mathrm{Pb}$, respectively. The Mazot power plant profile was enriched in vanadium $(\mathrm{V})$, which distinguishes heavy oil combustion emissions. Soluble potassium $\left(\mathrm{K}^{+}\right)$accounted for a large fraction of the $\mathrm{PM}_{2.5}$ $\mathrm{K}$ in the ambient samples. This is consistent with emissions from open (vegetative/trash) burning, which are prevalent in Cairo, because the ratio of water-soluble $\mathrm{K}^{+}$to total $\mathrm{K}$ is recognized as a marker for vegetative burning (Chow et al. 1992). While soluble $\mathrm{K}^{+}$is enriched in open (vegetative/ trash) burning emissions, it was essentially absent in the original CAIP refuse burning profile. Clearly, these limited measurements were not representative of burning emissions that impact air quality in Cairo. For this reason, we used a vegetative burning profile (RICEBURN2) from a US study (Chow and Watson 1999). Chow et al. (2007) found that $\mathrm{K}^{+}$was sufficient to distinguish vegetative burning from other combustion emissions.

Secondary particulates are not emitted directly but are formed from gas-to-particle chemical reactions in the atmosphere. Pure secondary ammonium sulfate (AMSUL), ammonium bisulfate (AMBSUL), sulfuric acid $\left(\mathrm{H}_{2} \mathrm{SO}_{4}\right)$, and ammonium chloride (AMCL) source profiles were needed to account for these compounds in ambient PM. Sea salt profiles, needed to account for soluble $\mathrm{Na}^{+}$in the ambient samples, were used to represent marine-derived

Table 1 Description of source profiles used in Cairo CMB source apportionment

\begin{tabular}{|c|c|c|c|}
\hline Abbreviations & Source ID & Description & Reference \\
\hline Geol & BSSOIL & El-Zamalek soil & CAIP \\
\hline Geol & HESOIL & Helwan soil & CAIP \\
\hline Geol & KASOIL & Kaha soil & CAIP \\
\hline Geol & ELMAUPRD & El-Maa'sara unpaved road & CAIP \\
\hline Geol & QUAPVRD & El-Qualaly paved road & CAIP \\
\hline Geol & SHOBUPRD & Shobra unpaved road & CAIP \\
\hline Geol & KAHAUPRD & Kaha unpaved road & CAIP \\
\hline Geol & LIME & Pure $\mathrm{CaCO}_{3}$ & Pure COMPOUND \\
\hline MV & MVSHERAT & Motor Vehicle (mixed) & CAIP \\
\hline $\mathrm{Pb}$ & LEADAVE & Lead smelter & CAIP \\
\hline $\mathrm{Cu}$ & CUFOUNDR & Copper foundry & CAIP \\
\hline Cem & TCEMENT & Cement plant & CAIP \\
\hline $\mathrm{Fe}$ & FESCRAP & Scrap iron production & CAIP \\
\hline Oil & MAZOTPP & Mazot oil power plant & CAIP \\
\hline Veg & RICEBURN2 & Vegetative burning & Chow and Watson (1999) \\
\hline Secsul & $\mathrm{H}_{2} \mathrm{SO}_{4}$ & Secondary sulfuric acid & Pure COMPOUND \\
\hline Secsul & AMBSUL & Secondary ammonium bisulfate & Pure COMPOUND \\
\hline Secsul & AMSUL & Secondary ammonium sulfate & Pure COMPOUND \\
\hline Secnit & AMNIT & Secondary ammonium nitrate & Pure COMPOUND \\
\hline $\mathrm{SecCl}$ & $\mathrm{NH}_{4} \mathrm{CL}$ & Secondary ammonium chloride & Pure COMPOUND \\
\hline Mar & MAR100 & Pure sea salt & Watson et al. (1994) \\
\hline Mar & MAR75 & Sea salt $25 \%$ nitrate replacement & Watson et al. (1994) \\
\hline Mar & MAR50 & Sea salt $50 \%$ nitrate replacement & Watson et al. (1994) \\
\hline Mar & MAR25 & Sea salt $75 \%$ nitrate replacement & Watson et al. (1994) \\
\hline Mar & MAR0 & Sea salt $100 \%$ nitrate replacement & Watson et al. (1994) \\
\hline
\end{tabular}


aerosols. Gaseous nitric acid $\left(\mathrm{HNO}_{3}\right)$ reacts with pure sea salt (MAR100) to form sodium nitrate and releases gaseous $\mathrm{HCl}$ (Mamane and Gottlieb 1992). The percent of chloride remaining after nitrate replacement is denoted in the sea salt profile ID, e.g., MAR25 represents $75 \%$ nitrate replacement. The AMCL profile was used to account for high chlorine concentrations in excess of the marine contribution.

The most significant requirement for successful CMB source attribution is that the source profiles are representative of the source emissions in the air shed. For the Cairo studies, local emissions were characterized for mobile, geological, and industrial sources. It is also the case that source profiles may vary over short and long time scales. Source apportionment studies frequently use profiles from data bases such as the US EPA SPECIATE source profile library (US EPA 2008). In many cases, such profiles were determined at different times and locations from the ambient PM studies. Even with realistic source profiles, it may not be possible to differentiate sources whose emissions have similar chemical composition. This is particularly the case for combustion sources, for example, diesel and gasoline vehicles, cooking, and open (vegetative/trash) burning which all emit EC and OC in various proportions. Resuspended paved and unpaved road dust and soil dust are generally quite similar in terms of their major elemental (e.g., $\mathrm{Al}, \mathrm{Si}, \mathrm{Fe}, \mathrm{Ca}$ ) composition. Industrial processes that use the same type of fuel may be also difficult to distinguish based on carbon emissions but specific processes can release unique trace elements, e.g., $\mathrm{Pb}$ from lead smelters, nickel $(\mathrm{Ni})$ and $\mathrm{V}$ from heavy oil combustion, copper $(\mathrm{Cu})$ from copper smelters, zinc $(\mathrm{Zn})$ from incineration and metal production and processing.

\section{Results and discussion}

\section{Ambient measurements}

Average $\mathrm{PM}_{2.5}$ and $\mathrm{PM}_{10}$ and selected chemical concentrations are presented for June (summer) and October (fall), 2010 in Tables 2 and 3, respectively. The mass measurements for $\mathrm{PM}_{10}$ mass, $\mathrm{PM}_{10}$ silicon $(\mathrm{Si})$ and $\mathrm{PM}_{2.5}$ lead $(\mathrm{Pb})$ are presented as time series plots for June and October, 2010 in Fig. 2. Silicon is a marker for geological material and the correspondence between the $\mathrm{PM}_{10}$ mass and $\mathrm{PM}_{10}$ Si time series illustrates the significance of geological sources. Lead, a highly toxic inorganic pollutant, is found mainly in the $\mathrm{PM}_{2.5}$ size fraction. Average $\mathrm{PM}_{2.5}$ mass concentrations were higher during fall than summer at all sites except Helwan. This was also true for $\mathrm{PM}_{10}$ mass. $\mathrm{PM}_{10}$ exceeded $300 \mu \mathrm{g} / \mathrm{m}^{3}$ on October 14 , 2010 at Shobra. Note the peak in PM $_{10}$ which occurred at all sites on June 11, 2010. A similar $\mathrm{PM}_{10}$ peak was also seen on October 14 and 16, 2010 at all sites. These peaks are also seen for $\mathrm{PM}_{2.5}$ mass. The geological origin of these high mass concentrations is apparent from the $\mathrm{Si}$ time series. The Si peaks are consistent with the mass peaks and indicate resuspended dust events during these periods.

Tables 2 and 3 show that average $\mathrm{PM}_{2.5}$ and $\mathrm{PM}_{10} \mathrm{~Pb}$ concentrations were higher during fall at all sites. The highest average $\mathrm{PM}_{10} \mathrm{~Pb}$ concentrations were found at Shobra $\left(0.67 \mu \mathrm{g} / \mathrm{m}^{3}\right)$ and El-Zamalek $\left(0.24 \mu \mathrm{g} / \mathrm{m}^{3}\right)$. Figure 2 indicates that the temporal trends in $\mathrm{PM}_{2.5}$ and $\mathrm{PM}_{10} \mathrm{~Pb}$ were similar. The highest $\mathrm{Pb}$ concentrations occurred at Shobra. Concentrations were higher during fall than summer. During summer, $\mathrm{Pb}$ concentrations were uniformly low at all sites except Shobra. During fall, there were episodic periods with elevated $\mathrm{Pb}$ at all sites on October 20, 2010 and at Shobra, El-Zamalek and El-Qualaly on October 26, 2010. These patterns suggest that Shobra remains a hot spot for $\mathrm{Pb}$ emissions and that other sites experienced transport from Shobra under the appropriate meteorological conditions.

Soluble $\mathrm{K}^{+}$is a useful marker for biomass burning (Chow et al. 2007). Roughly 10-15\% of geological K is soluble. The average ratio of soluble to total $\mathrm{K}$ in all Cairo $\mathrm{PM}_{2.5}$ samples was $0.90 \pm 0.23(0.80 \pm 0.23$ in summer and $1.00 \pm 0.28$ in fall). These high ratios indicate the presence of biomass burning. Table 2 shows higher $\mathrm{PM}_{2.5}$ $\mathrm{K}^{+}$concentrations in fall than summer at all sites. This could be due to a higher burning source activity during fall or to meteorological factors such as lower mixing height or wind direction. Table 2 shows that while $\mathrm{PM}_{2.5}$ EC concentration (which comes from all combustion sources) was somewhat higher during fall, the seasonal difference was not as great as for $\mathrm{K}^{+}$. This suggests that there was more open (vegetative/trash) burning during fall than summer. Table 2 indicates that the highest average $\mathrm{PM}_{2.5} \mathrm{~K}^{+}$concentrations were found at the background site Kaha $\left(2.2 \mu \mathrm{g} / \mathrm{m}^{3}\right)$ during fall and at Shobra $\left(1.46 \mu \mathrm{g} / \mathrm{m}^{3}\right)$ during fall. Average sulfate $\left(\mathrm{SO}_{4}{ }^{2-}\right)$ concentrations were higher during summer than fall at all sites in both size fractions. Average $\mathrm{SO}_{4}{ }^{2-}$ concentrations during summer showed very little variation $\left(7.1 \pm 0.2 \mu \mathrm{g} / \mathrm{m}^{3}\right)$ across the five sites, demonstrating the secondary character of this species.

Source attribution results

Average CMB results for June and October, 2010 at each of the five sites are given for the $\mathrm{PM}_{2.5}$ and $\mathrm{PM}_{10}$ fractions in Table 4 for sources described in Table 1. Table 4 shows that the largest contributor to $\mathrm{PM}_{2.5}$ at all sites during summer was motor vehicles (MV). These contributions ranged from $11.4 \mu \mathrm{g} / \mathrm{m}^{3}$ at Kaha to $24 \mu \mathrm{g} / \mathrm{m}^{3}$ at El-Qualaly. There was a significant increase in the open (vegetative/ trash) burning (VEG) contribution in October. The VEG 


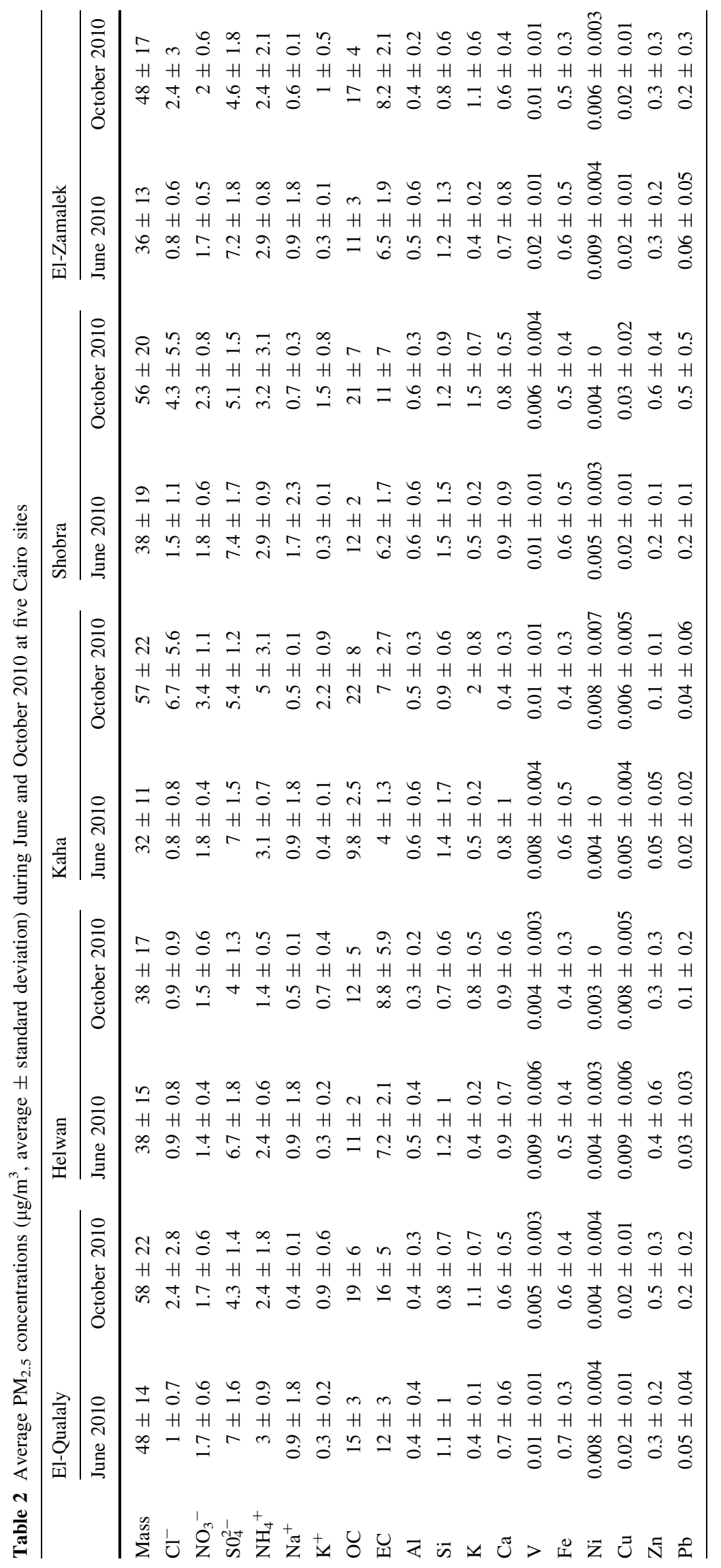




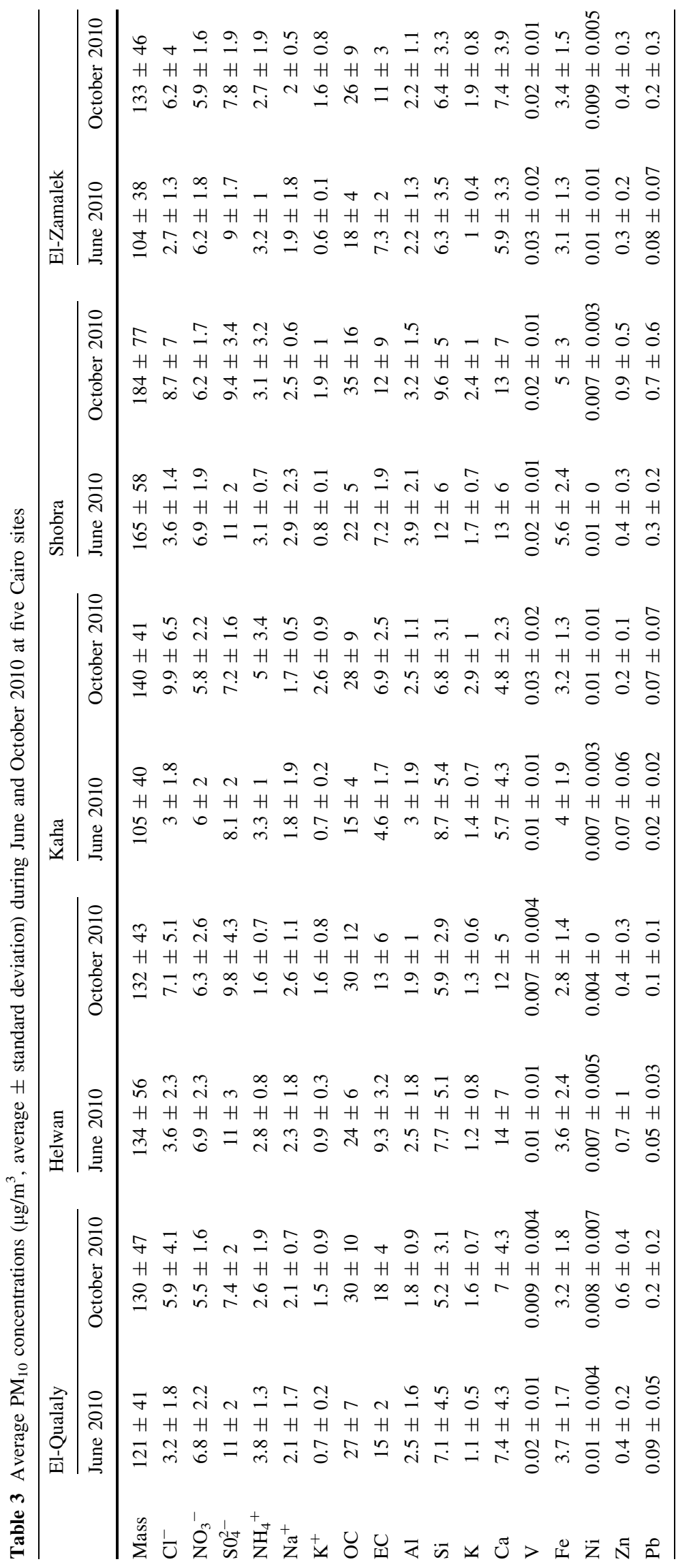




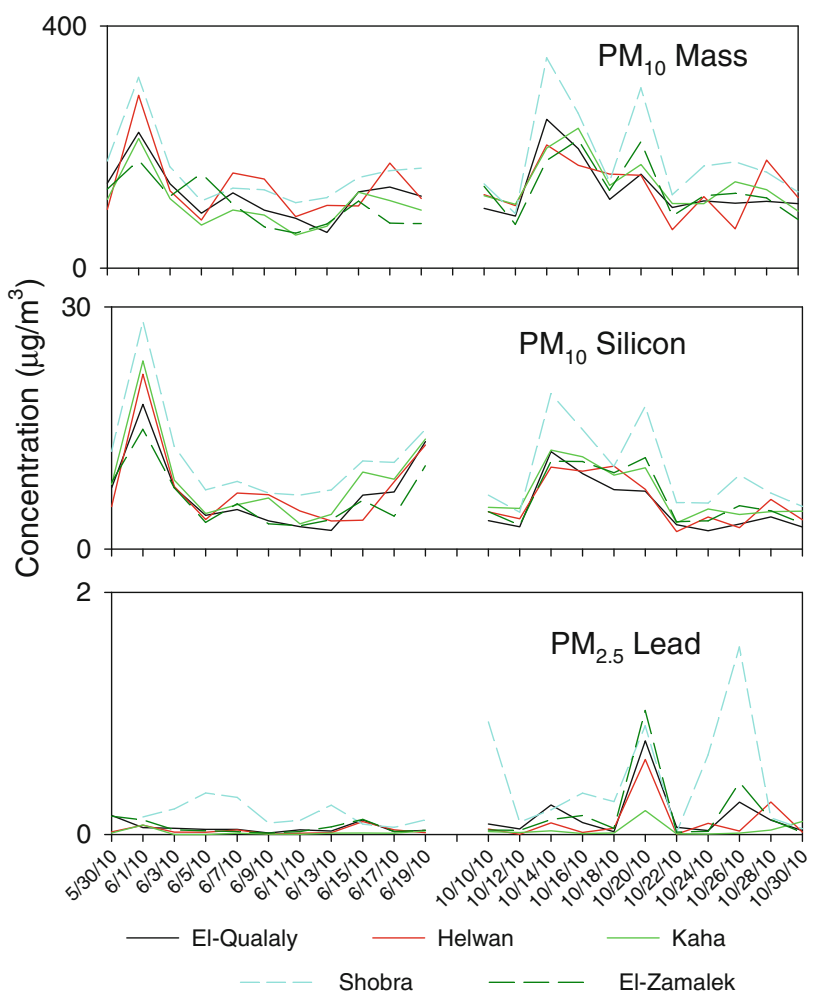

Fig. 2 Time series of $\mathrm{PM}_{10}$ mass, $\mathrm{PM}_{10}$ silicon, and $\mathrm{PM}_{2.5}$ lead at five Cairo sites

contribution increased from 3.3 to $15.0 \mu \mathrm{g} / \mathrm{m}^{3}$ at El-Qualaly, 4.9 to $8.9 \mu \mathrm{g} / \mathrm{m}^{3}$ at Helwan, 4.6 to $43 \mu \mathrm{g} / \mathrm{m}^{3}$ at Kaha, 5.5 to $33 \mu \mathrm{g} / \mathrm{m}^{3}$ at Shobra, and 3.8 to $22 \mu \mathrm{g} / \mathrm{m}^{3}$ at El-Qualaly. This is consistent with the large increases in soluble $\mathrm{K}^{+}$concentrations at all sites during fall (see Tables 2,3) and likely results from the burning of agricultural waste (rice straw) following the fall harvest (Favez et al. 2008; Marey et al. 2010, 2011).

The geological source contribution to $\mathrm{PM}_{2.5}$ was also significant at all sites, ranging from $5.1 \mu \mathrm{g} / \mathrm{m}^{3}(10.8 \%)$ at El-Qualaly to $8.6 \mu \mathrm{g} / \mathrm{m}^{3}$ (23 \%) at Kaha during summer. The absolute and relative geological source contributions decreased during the fall season, ranging from $2.4 \mu \mathrm{g} / \mathrm{m}^{3}$ $(7.0 \%)$ at Helwan to $5.4 \mu \mathrm{g} / \mathrm{m}^{3}(7.4 \%)$ at Shobra. This could indicate drier and windier conditions in summer than in fall and is also consistent with lower mixing heights during fall (Pye 1989).

Secondary sulfate (SECSUL) was a major contributor to $\mathrm{PM}_{2.5}$ during summer 2010, ranging from $16.7 \%$ at El-Qualaly to $23 \%$ at Kaha. The relative contribution of SECSUL to $\mathrm{PM}_{2.5}$ decreased significantly during fall, ranging from $6 \%$ at El-Qualaly and Kaha to $8.3 \%$ at Helwan. The higher contribution during summer reflects greater photochemical activity during this period and the relatively small variations in SECSUL contributions over the five sites demonstrates regional-scale mixing of sulfur dioxide and its oxidation to sulfate.
The $\mathrm{Pb}$ smelter source contributed less than $1 \mu \mathrm{g} / \mathrm{m}^{3}$ to $\mathrm{PM}_{2.5}$ at all sites and seasons. However, because of its potential adverse impact on human health, it is notable that this source contribution to $\mathrm{PM}_{2.5}$ ranged from $0 \mu \mathrm{g} / \mathrm{m}^{3}$ at Helwan and Kaha to $0.22 \mu \mathrm{g} / \mathrm{m}^{3}(0.5 \%)$ at Shobra during summer and from $0.04 \mu \mathrm{g} / \mathrm{m}^{3}(0.1 \%)$ at Kaha to 0.65 $\mu \mathrm{g} / \mathrm{m}^{3}(0.9 \%)$ at Shobra during fall. This may be attributable to higher source emissions and/or to meteorological factors associated with colder temperatures and lower mixing heights in October.

The marine contribution to $\mathrm{PM}_{2.5}$ was significant, ranging from $2.8 \%$ at El-Qualaly and Kaha to $6.7 \%$ at Shobra during summer and $0 \%$ at Kaha to $1.9 \%$ at Helwan during fall. The marine contribution to $\mathrm{PM}_{10}$ was larger than its contribution to $\mathrm{PM}_{2.5}$, which is expected since marine aerosols are mainly in the coarse fraction. The magnitude of the estimated marine contribution depends on the degree of substitution of nitrate for chloride. We would expect the contributions to be roughly similar at all sites due to the distance from the upwind (the prevailing wind direction is from the north) marine source (the Mediterranean Sea is about 100 miles to the north). Indeed, average $\mathrm{Na}^{+}$concentrations (Tables 2,3) were quite similar at most sites, although $\mathrm{Na}^{+}$concentrations at Shobra were somewhat higher. This was the case for both $\mathrm{PM}_{2.5}$ and $\mathrm{PM}_{10}$ $\mathrm{Na}^{+}$.

Industrial source contributions other than $\mathrm{Pb}$ smelters were generally low. However, the large uncertainties for the cement plant and oil combustion contributions suggest the effects of collinearity involving their source profiles in the CMB solution. Nonetheless, as shown in Table 4, the largest cement plant contributions were seen at Helwan, particularly in the $\mathrm{PM}_{10}$ fraction. The Torah and Helwan cement companies are located in this area.

Geological dust was the largest contributor to $\mathrm{PM}_{10}$ at all sites, ranging from $36 \mu \mathrm{g} / \mathrm{m}^{3}$ (39\%) at El-Zamalek to $86 \mu \mathrm{g} / \mathrm{m}^{3}(58 \%)$ at Shobra. As with $\mathrm{PM}_{2.5}$, the geological contribution to $\mathrm{PM}_{10}$ decreased during the fall season, ranging from $29 \mu \mathrm{g} / \mathrm{m}^{3}(23 \%)$ at El-Qualaly to $53 \mu \mathrm{g} / \mathrm{m}^{3}$ $(31 \%)$ at Shobra. MV contributions to $\mathrm{PM}_{10}$ were similar to (within the estimation uncertainty) or somewhat higher than the corresponding contributions to $\mathrm{PM}_{2.5}$. This means that some of the motor vehicle contribution was in the coarse fraction. The open (vegetative/trash) burning contribution to $\mathrm{PM}_{10}$ was significantly higher than the corresponding contribution to $\mathrm{PM}_{2.5}$ at all sites. As seen for $\mathrm{PM}_{2.5}$, the open (vegetative/trash) burning contribution to $\mathrm{PM}_{10}$ was also significantly higher during fall than summer.

Distinguishing combustion source contributions with CMB modeling is difficult because the source profiles are typically similar, being dominated by carbon (EC and OC). While we used a vegetative burning source profile that was 
Table 4 Average CMB results $\left(\mu \mathrm{g} / \mathrm{m}^{3}\right.$ and percent of predicted mass) at 5 Cairo sites during summer and fall 2010

\begin{tabular}{|c|c|c|c|c|c|c|c|c|}
\hline \multicolumn{5}{|l|}{ PM 2.5} & \multicolumn{4}{|l|}{$\mathrm{PM}_{10}$} \\
\hline \multicolumn{3}{|l|}{ June 2010} & \multicolumn{2}{|c|}{ October 2010} & \multicolumn{2}{|l|}{ June 2010} & \multicolumn{2}{|l|}{ October 2010} \\
\hline & $\mu \mathrm{g} / \mathrm{m}^{3}$ & $\%$ & $\mu \mathrm{g} / \mathrm{m}^{3}$ & $\%$ & $\mu \mathrm{g} / \mathrm{m}^{3}$ & $\%$ & $\mu \mathrm{g} / \mathrm{m}^{3}$ & $\%$ \\
\hline \multicolumn{9}{|l|}{ El-Qualaly } \\
\hline Geological & $5.1 \pm 0.5$ & 10.8 & $3.0 \pm 0.5$ & 5.5 & $52 \pm 6$ & 42 & $29 \pm 4$ & 23 \\
\hline $\mathrm{Pb}$ smelter & $0.02 \pm 0.01$ & 0.0 & $0.16 \pm 0.03$ & 0.3 & $0.02 \pm 0.01$ & 0.0 & $0.06 \pm 0.02$ & 0.0 \\
\hline $\mathrm{Cu}$ smelter & $0.34 \pm 0.05$ & 0.7 & $0.67 \pm 0.08$ & 1.2 & $0.34 \pm 0.06$ & 0.3 & $0.71 \pm 0.09$ & 0.6 \\
\hline Fe foundry & $1.38 \pm 0.22$ & 2.9 & $1.45 \pm 0.26$ & 2.6 & $3.5 \pm 0.7$ & 2.8 & $5.1 \pm 0.8$ & 4.1 \\
\hline Cement plant & $0.63 \pm 0.70$ & 1.3 & $1.63 \pm 1.81$ & 2.9 & $1.15 \pm 1.41$ & 0.9 & $4.5 \pm 3.6$ & 3.6 \\
\hline Oil comb. & $1.58 \pm 1.61$ & 3.4 & $1.66 \pm 1.38$ & 3.0 & $0.22 \pm 0.39$ & 0.2 & $0.44 \pm 0.40$ & 0.3 \\
\hline Motor veh. & $24 \pm 2$ & 51 & $25 \pm 3$ & 44 & $32 \pm 4$ & 26 & $31 \pm 4$ & 25 \\
\hline Open burn & $3.3 \pm 0.6$ & 7.0 & $14.9 \pm 1.6$ & 7.0 & $14.7 \pm 2.2$ & 12.0 & $41 \pm 4$ & 32 \\
\hline Marine & $1.34 \pm 0.33$ & 2.8 & $0.26 \pm 0.12$ & 0.5 & $5.7 \pm 0.9$ & 4.6 & $5.4 \pm 0.8$ & 4.3 \\
\hline Sec. sulfate & $7.9 \pm 0.8$ & 16.7 & $3.3 \pm 0.6$ & 6.0 & $9.3 \pm 1.3$ & 7.6 & $4.0 \pm 1.2$ & 3.2 \\
\hline Sec. nitrate & $1.48 \pm 0.28$ & 3.1 & $1.84 \pm 0.31$ & 3.3 & $3.6 \pm 0.9$ & 2.9 & $1.71 \pm 0.79$ & 1.4 \\
\hline Sec. chloride & $0.13 \pm 0.08$ & 0.3 & $1.71 \pm 0.28$ & 3.1 & $0.33 \pm 0.30$ & 0.3 & $2.4 \pm 0.7$ & 1.9 \\
\hline Measured & $48 \pm 2$ & & $58 \pm 2$ & & $121 \pm 2$ & & $130 \pm 3$ & \\
\hline Predicted & $47 \pm 3$ & & $55 \pm 4$ & & $122 \pm 7$ & & $126 \pm 8$ & \\
\hline \multicolumn{9}{|l|}{ Helwan } \\
\hline Geological & $7.2 \pm 0.6$ & 17.8 & $2.3 \pm 0.4$ & 7.0 & $46 \pm 6$ & 38 & $38 \pm 5$ & 29 \\
\hline $\mathrm{Pb}$ smelter & $0.00 \pm 0.00$ & 0.0 & $0.10 \pm 0.03$ & 0.3 & $0.00 \pm 0.00$ & 0.0 & $0.08 \pm 0.02$ & 0.1 \\
\hline $\mathrm{Cu}$ smelter & $0.57 \pm 0.08$ & 1.4 & $0.37 \pm 0.05$ & 1.1 & $0.81 \pm 0.11$ & 0.7 & $0.48 \pm 0.07$ & 0.4 \\
\hline Fe foundry & $0.66 \pm 0.16$ & 1.6 & $0.21 \pm 0.13$ & 0.6 & $1.60 \pm 0.58$ & 1.3 & $1.73 \pm 0.59$ & 1.3 \\
\hline Cement plant & $2.0 \pm 1.5$ & 5.0 & $4.8 \pm 2.1$ & 4.4 & $17.3 \pm 9.0$ & 14.5 & $11.1 \pm 7.5$ & 8.5 \\
\hline Oil comb. & $1.12 \pm 1.27$ & 2.8 & $1.36 \pm 1.21$ & 4.1 & $0.37 \pm 0.44$ & 0.3 & $0.08 \pm 0.23$ & 0.1 \\
\hline Motor veh. & $13.9 \pm 1.8$ & 34.5 & $11.0 \pm 1.8$ & 2.8 & $13.2 \pm 2.9$ & 11.1 & $15.1 \pm 3.1$ & 11.5 \\
\hline Open burn & $4.9 \pm 0.7$ & 12.2 & $8.9 \pm 1.4$ & 6.5 & $24 \pm 3$ & 21 & $49 \pm 5$ & 37 \\
\hline Marine & $1.78 \pm 0.37$ & 4.4 & $0.65 \pm 0.16$ & 1.9 & $5.5 \pm 0.7$ & 4.6 & $7.1 \pm 1.0$ & 5.4 \\
\hline Sec. sulfate & $7.2 \pm 0.7$ & 17.8 & $2.8 \pm 0.5$ & 8.3 & $7.0 \pm 1.4$ & 5.9 & $6.9 \pm 1.1$ & 5.3 \\
\hline Sec. nitrate & $0.73 \pm 0.21$ & 1.8 & $1.00 \pm 0.24$ & 3.0 & $2.6 \pm 0.9$ & 2.2 & $1.8 \pm 0.61$ & 1.4 \\
\hline Sec. chloride & $0.28 \pm 0.10$ & 0.7 & $0.00 \pm 0.00$ & 0.0 & $0.36 \pm 0.68$ & 0.3 & $0.08 \pm 0.22$ & 0.1 \\
\hline Measured & $39 \pm 2$ & & $38 \pm 1$ & & $138 \pm 3$ & & $132 \pm 3$ & \\
\hline Predicted & $40 \pm 3$ & & $34 \pm 3$ & & $119 \pm 12$ & & $131 \pm 11$ & \\
\hline \multicolumn{9}{|l|}{ Kaha } \\
\hline Geological & $8.6 \pm 0.6$ & 23 & $3.9 \pm 0.4$ & 5.1 & $54 \pm 4$ & 54 & $39 \pm 4$ & 26 \\
\hline $\mathrm{Pb}$ smelter & $0.00 \pm 0.00$ & 0.0 & $0.04 \pm 0.01$ & 0.1 & $0.00 \pm 0.01$ & 0.0 & $0.06 \pm 0.01$ & 0.0 \\
\hline $\mathrm{Cu}$ smelter & $0.02 \pm 0.01$ & 0.1 & $0.15 \pm 0.02$ & 0.2 & $0.07 \pm 0.02$ & 0.1 & $0.19 \pm 0.03$ & 0.1 \\
\hline Fe foundry & $0.54 \pm 0.13$ & 1.4 & $0.30 \pm 0.15$ & 0.4 & $0.01 \pm 0.48$ & 0.0 & $0.83 \pm 0.66$ & 0.6 \\
\hline Cement plant & $0.00 \pm 0.00$ & 0.0 & $0.14 \pm 0.33$ & 0.2 & $1.04 \pm 3.50$ & 1.0 & $2.5 \pm 3.5$ & 1.6 \\
\hline Oil comb. & $0.81 \pm 1.21$ & 2.1 & $1.77 \pm 1.07$ & 2.3 & $0.65 \pm 0.33$ & 0.7 & $1.36 \pm 0.45$ & 0.9 \\
\hline Motor veh. & $11.4 \pm 1.3$ & 30 & $12.7 \pm 2.1$ & 6.8 & $8.6 \pm 1.4$ & 8.6 & $9.2 \pm 2.1$ & 6.1 \\
\hline Open burn & $4.6 \pm 0.6$ & 12.3 & $43 \pm 3$ & 57 & $18.0 \pm 2.1$ & 18.1 & $76 \pm 6$ & 50.7 \\
\hline Marine & $1.05 \pm 0.22$ & 2.8 & $0.00 \pm 0.05$ & 0.0 & $5.0 \pm 0.7$ & 5.0 & $3.3 \pm 0.7$ & 2.2 \\
\hline Sec. sulfate & $8.5 \pm 0.8$ & 23 & $6.0 \pm 0.8$ & 7.9 & $7.3 \pm 1.2$ & 7.4 & $6.3 \pm 2.6$ & 4.2 \\
\hline Sec. nitrate & $1.68 \pm 0.26$ & 4.5 & $4.5 \pm 0.5$ & 6.0 & $4.0 \pm 0.7$ & 4.1 & $4.2 \pm 1.0$ & 2.8 \\
\hline Sec. chloride & $0.42 \pm 0.10$ & 1.1 & $3.0 \pm 0.5$ & 3.9 & $0.87 \pm 0.40$ & 0.9 & $7.2 \pm 1.4$ & 4.8 \\
\hline Measured & $32 \pm 1$ & & $57 \pm 2$ & & $105 \pm 2$ & & $140 \pm 3$ & \\
\hline Predicted & $38 \pm 2$ & & $76 \pm 4$ & & $99 \pm 6$ & & $150 \pm 9$ & \\
\hline
\end{tabular}


Table 4 continued

\begin{tabular}{|c|c|c|c|c|c|c|c|c|}
\hline \multicolumn{5}{|l|}{ PM 2.5} & \multicolumn{4}{|l|}{$\mathrm{PM}_{10}$} \\
\hline \multicolumn{3}{|l|}{ June 2010} & \multicolumn{2}{|l|}{ October 2010} & \multicolumn{2}{|l|}{ June 2010} & \multicolumn{2}{|l|}{ October 2010} \\
\hline & $\mu \mathrm{g} / \mathrm{m}^{3}$ & $\%$ & $\mu \mathrm{g} / \mathrm{m}^{3}$ & $\%$ & $\mu \mathrm{g} / \mathrm{m}^{3}$ & $\%$ & $\mu \mathrm{g} / \mathrm{m}^{3}$ & $\%$ \\
\hline \multicolumn{9}{|l|}{ Shobra } \\
\hline Geological & $8.1 \pm 0.6$ & 18.8 & $5.4 \pm 0.6$ & 7.4 & $86 \pm 6$ & 58 & $53 \pm 8$ & 31 \\
\hline $\mathrm{Pb}$ smelter & $0.22 \pm 0.03$ & 0.5 & $0.65 \pm 0.09$ & 0.9 & $0.33 \pm 0.05$ & 0.2 & $0.83 \pm 0.12$ & 0.5 \\
\hline $\mathrm{Cu}$ smelter & $0.31 \pm 0.04$ & 0.7 & $0.95 \pm 0.11$ & 1.3 & $0.54 \pm 0.07$ & 0.4 & $1.22 \pm 0.15$ & 0.7 \\
\hline Fe foundry & $0.74 \pm 0.19$ & 1.7 & $1.12 \pm 0.24$ & 1.6 & $1.00 \pm 1.01$ & 0.7 & $5.2 \pm 1.3$ & 3.1 \\
\hline Cement plant & $0.70 \pm 0.76$ & 1.6 & $2.2 \pm 2.0$ & 3.0 & $0.00 \pm 0.00$ & 0.0 & $12.6 \pm 10.7$ & 7.5 \\
\hline Oil comb. & $1.58 \pm 1.39$ & 3.7 & $1.48 \pm 1.38$ & 2.1 & $0.68 \pm 0.54$ & 0.5 & $0.31 \pm 0.49$ & 0.2 \\
\hline Motor veh. & $13.6 \pm 1.6$ & 32 & $16.9 \pm 3.0$ & 23 & $16.6 \pm 2.4$ & 11.2 & $19.9 \pm 3.9$ & 11.9 \\
\hline Open burn & $5.5 \pm 0.7$ & 12.7 & $33 \pm 3$ & 46 & $24 \pm 3$ & 16.4 & $59 \pm 6$ & 35 \\
\hline Marine & $2.9 \pm 0.5$ & 6.7 & $0.51 \pm 0.26$ & 0.7 & $7.5 \pm 1.1$ & 5.1 & $6.3 \pm 0.9$ & 3.8 \\
\hline Sec. sulfate & $8.5 \pm 0.8$ & 19.8 & $4.3 \pm 0.7$ & 6.0 & $7.5 \pm 1.5$ & 5.0 & $4.7 \pm 1.70$ & 2.8 \\
\hline Sec. nitrate & $0.73 \pm 0.30$ & 1.7 & $2.2 \pm 0.4$ & 3.1 & $2.9 \pm 0.9$ & 2.0 & $1.7 \pm 0.88$ & 1.0 \\
\hline Sec. chloride & $0.15 \pm 0.08$ & 0.3 & $3.2 \pm 0.7$ & 4.5 & $0.62 \pm 0.70$ & 0.4 & $4.3 \pm 1.0$ & 2.5 \\
\hline Measured & $38 \pm 1$ & & $56 \pm 2$ & & $165 \pm 3$ & & $184 \pm 3$ & \\
\hline Predicted & $43 \pm 3$ & & $72 \pm 5$ & & $148 \pm 7$ & & $168 \pm 15$ & \\
\hline \multicolumn{9}{|l|}{ El-Zamalek } \\
\hline Geological & $6.4 \pm 0.5$ & 16.0 & $3.4 \pm 0.4$ & 6.4 & $36 \pm 3$ & 39 & $33 \pm 5$ & 26 \\
\hline $\mathrm{Pb}$ smelter & $0.03 \pm 0.01$ & 0.1 & $0.23 \pm 0.05$ & 0.4 & $0.03 \pm 0.01$ & 0.0 & $0.24 \pm 0.05$ & 0.2 \\
\hline $\mathrm{Cu}$ smelter & $0.36 \pm 0.05$ & 0.9 & $0.50 \pm 0.06$ & 0.9 & $0.39 \pm 0.05$ & 0.4 & $0.60 \pm 0.08$ & 0.5 \\
\hline Fe foundry & $1.02 \pm 0.19$ & 2.5 & $1.03 \pm 0.20$ & 1.9 & $0.97 \pm 0.54$ & 1.0 & $2.60 \pm 0.76$ & 2.1 \\
\hline Cement plant & $0.15 \pm 0.30$ & 0.4 & $1.18 \pm 1.07$ & 2.2 & $2.1 \pm 3.7$ & 2.2 & $4.2 \pm 4.5$ & 3.4 \\
\hline Oil comb. & $2.5 \pm 1.4$ & 6.1 & $2.4 \pm 1.3$ & 4.4 & $0.66 \pm 0.45$ & 0.7 & $0.49 \pm 0.49$ & 0.4 \\
\hline Motor veh. & $15.0 \pm 1.6$ & 37 & $15.1 \pm 2.1$ & 28 & $17.3 \pm 2.3$ & 18.8 & $21 \pm 3$ & 16.6 \\
\hline Open burn & $3.8 \pm 0.5$ & 9.5 & $22 \pm 2$ & 40 & $17.7 \pm 1.9$ & 19.2 & $48 \pm 4$ & 38 \\
\hline Marine & $1.40 \pm 0.30$ & 3.5 & $0.71 \pm 0.21$ & 1.3 & $5.4 \pm 0.8$ & 5.8 & $5.5 \pm 0.9$ & 4.3 \\
\hline Sec. sulfate & $8.2 \pm 0.8$ & 20 & $3.7 \pm 0.7$ & 7.0 & $7.9 \pm 1.3$ & 8.5 & $4.8 \pm 2.2$ & 3.8 \\
\hline Sec. nitrate & $1.23 \pm 0.27$ & 3.1 & $1.75 \pm 0.35$ & 3.3 & $3.5 \pm 0.8$ & 3.8 & $2.3 \pm 1.1$ & 1.8 \\
\hline Sec. chloride & $0.19 \pm 0.07$ & 0.5 & $1.97 \pm 0.71$ & 3.7 & $0.30 \pm 0.44$ & 0.3 & $3.1 \pm 1.1$ & 2.5 \\
\hline Measured & $36 \pm 1$ & & $48 \pm 2$ & & $104 \pm 2$ & & $133 \pm 3$ & \\
\hline Predicted & $40 \pm 2$ & & $54 \pm 4$ & & $92 \pm 6$ & & $126 \pm 9$ & \\
\hline
\end{tabular}
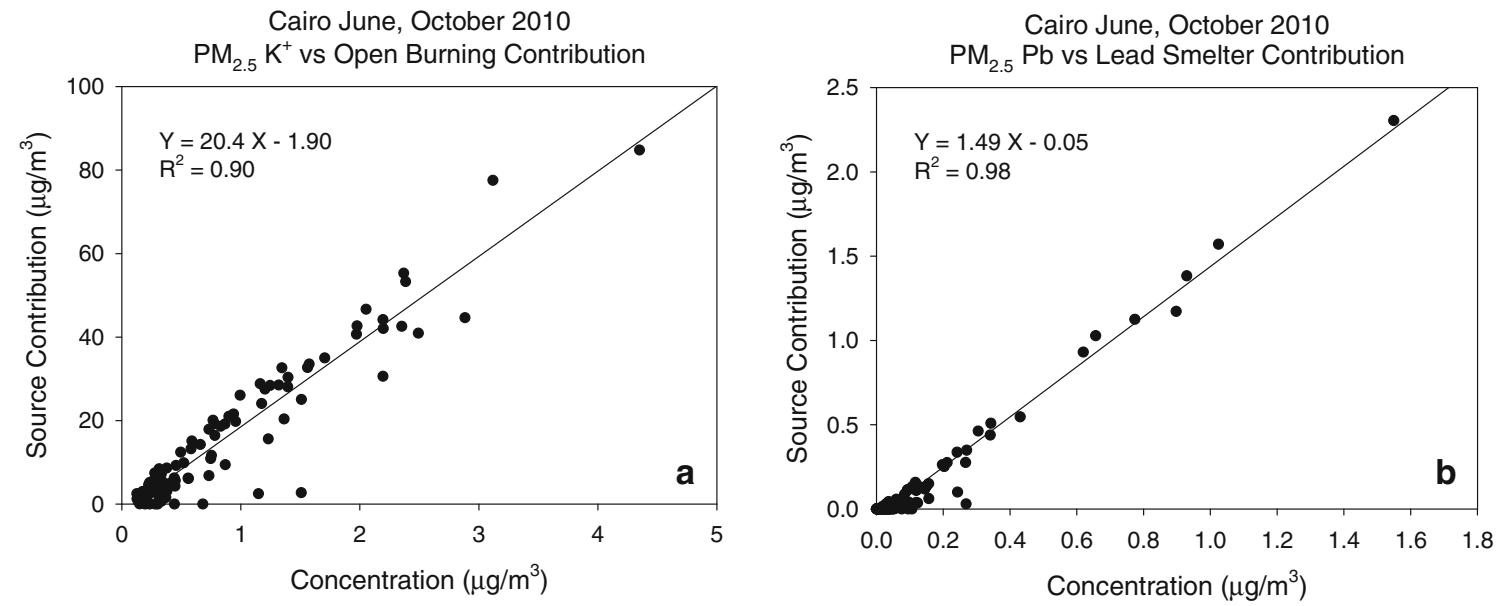

Fig. 3 Relationships between $\mathrm{PM}_{2.5}$ open (vegetative/trash) burning source contributions and $\mathrm{K}^{+}$(a) and between lead smelter source contributions and $\mathrm{Pb}(\mathbf{b})$ 
Table 5 Trends in seasonal average concentrations $\left(\mu \mathrm{g} / \mathrm{m}^{3}\right)$ for mass and lead in Cairo from 1999 to 2010

\begin{tabular}{|c|c|c|c|c|c|c|c|c|}
\hline & Size & Sampling period & El-Zamalek & El-Qualaly & Helwan & Kaha & Shobra & Average \\
\hline \multirow[t]{10}{*}{ Mass } & \multirow[t]{5}{*}{ PM10 } & Winter 1999 & 127 & 220 & 88 & 93 & 265 & 159 \\
\hline & & Fall 1999 & 249 & 252 & 146 & 205 & 360 & 242 \\
\hline & & Summer 2002 & 99 & 136 & 142 & 100 & 154 & 126 \\
\hline & & Fall 2010 & 133 & 130 & 132 & 140 & 184 & 144 \\
\hline & & Summer 2010 & 104 & 121 & 134 & 105 & 165 & 126 \\
\hline & \multirow[t]{5}{*}{ PM2.5 } & Winter 1999 & 62 & 85 & 29 & 50 & 216 & 88 \\
\hline & & Fall 1999 & 132 & 135 & 100 & 111 & 174 & 130 \\
\hline & & Summer 2002 & 40 & 59 & 48 & 35 & 61 & 48 \\
\hline & & Fall 2010 & 48 & 58 & 38 & 57 & 57 & 52 \\
\hline & & Summer 2010 & 36 & 48 & 38 & 32 & 38 & 38 \\
\hline \multirow[t]{10}{*}{ Lead } & \multirow[t]{5}{*}{ PM10 } & Winter 1999 & 1.6 & 4.8 & 0.2 & 0.1 & 34 & 8.1 \\
\hline & & Fall 1999 & 1 & 1.8 & 0.3 & 0.1 & 12.7 & 3.2 \\
\hline & & Summer 2002 & 0.2 & 0.5 & 0.2 & 0 & 7.2 & 1.6 \\
\hline & & Fall 2010 & 0.2 & 0.2 & 0.1 & 0.1 & 0.7 & 0.3 \\
\hline & & Summer 2010 & 0.1 & 0.1 & 0 & 0 & 0.3 & 0.1 \\
\hline & \multirow[t]{5}{*}{ PM2.5 } & Winter 1999 & 0.7 & 1.6 & 0.1 & 0 & 27 & 5.8 \\
\hline & & Fall 1999 & 0.7 & 1.4 & 0.2 & 0.1 & 9.2 & 2.3 \\
\hline & & Summer 2002 & 0.1 & 0.3 & 0.1 & 0 & 5.1 & 1.1 \\
\hline & & Fall 2010 & 0.2 & 0.2 & 0.1 & 0 & 0.5 & 0.2 \\
\hline & & Summer 2010 & 0.1 & 0.1 & 0 & 0 & 0.2 & 0.1 \\
\hline
\end{tabular}

not specific to Cairo, we are confident that this contribution was reliably distinguished from other combustion sources, e.g., MV. Figure 3a compares $\mathrm{PM}_{2.5}$ soluble $\mathrm{K}^{+}$and the corresponding open (vegetative/trash) burning contribution for individual samples. The relationship is strong, with $R^{2}=0.90$. While the relative variations of the estimated open (vegetative/trash) burning contributions are probably realistic, the absolute value of this source contribution is accurate to the degree that the source profile used in the $\mathrm{CMB}$ has the same $\mathrm{K}^{+}$composition as the open (vegetative/trash) burning emissions in Cairo. Similarly, Fig. 3b shows the relationship between $\mathrm{PM}_{2.5}$ lead $(\mathrm{Pb})$ and the corresponding lead smelter source contribution. In this case, the relationship is also very strong $\left(R^{2}=0.98\right)$.

PM source attribution in Cairo for 1999, 2002, and 2010

Table 5 presents seasonally averaged $\mathrm{PM}_{2.5}$ and $\mathrm{PM}_{10}$ mass and lead concentrations at the five sampling sites for 1999, 2002, and 2010. Results for 1999 and 2002 were taken from Abu-Allaban et al. (2007). $\mathrm{PM}_{2.5}$ mass concentrations were significantly lower during fall 2010 compared with fall 1999 at all sites. This is also the case for $\mathrm{PM}_{10}$ mass at all sites; however, the difference was smaller at Helwan. Summer $\mathrm{PM}_{2.5}$ concentrations were somewhat lower (generally within $20 \%$ ) in 2010 compared with 2002. The difference was most dramatic at Shobra (37\%). There was no significant trend for $\mathrm{PM}_{10}$ between summer 2002 and summer 2010. $\mathrm{PM}_{10}$ and $\mathrm{PM}_{2.5}$ mass concentrations averaged over the five sites peaked at 242 and $130 \mu \mathrm{g} / \mathrm{m}^{3}$, respectively, during fall 1999, and decreased and remained relatively constant thereafter. It should be emphasized that inter-seasonal variations may be due in part to meteorological factors such as wind speed and direction and mixing height, as well as differences in emission strength. However, it is not feasible to quantify these effects.

By contrast, $\mathrm{PM}_{2.5}$ and $\mathrm{PM}_{10} \mathrm{~Pb}$ concentrations decreased dramatically from 1999 to 2010. The largest change was at Shobra, where $\mathrm{PM}_{10} \mathrm{~Pb}$ decreased from $34 \mu \mathrm{g} / \mathrm{m}^{3}$ during winter 1999 to $0.3 \mu \mathrm{g} / \mathrm{m}^{3}$ during summer, 2010. $\mathrm{PM}_{10} \mathrm{~Pb}$ at Shobra also decreased significantly from 34 to $12.7 \mu \mathrm{g} / \mathrm{m}^{3}$ between winter and fall 1999. A similar decrease in $\mathrm{PM}_{10} \mathrm{~Pb}$ by a factor of 2.7 over this period occurred at El-Qualaly. Large decreases in $\mathrm{PM}_{10} \mathrm{~Pb}$ between the summers of 2002 and 2010 were seen at Shobra and El-Qualaly. Similar trends are seen for $\mathrm{PM}_{2.5}$ $\mathrm{Pb}$.

Table 6 presents the relative source contributions to $\mathrm{PM}_{2.5}$ and $\mathrm{PM}_{10}$, respectively, as a percent of total predicted mass. The values represent seasonal averages over the five sampling sites. Geological material is the dominant source of $\mathrm{PM}_{10}$ mass. The geological contribution to $\mathrm{PM}_{10}$ peaked during the summer of 2002 due to high contributions at El-Qualaly, El-Zamalek, and Helwan and during the summer of 2010 due to high contributions at Kaha and 


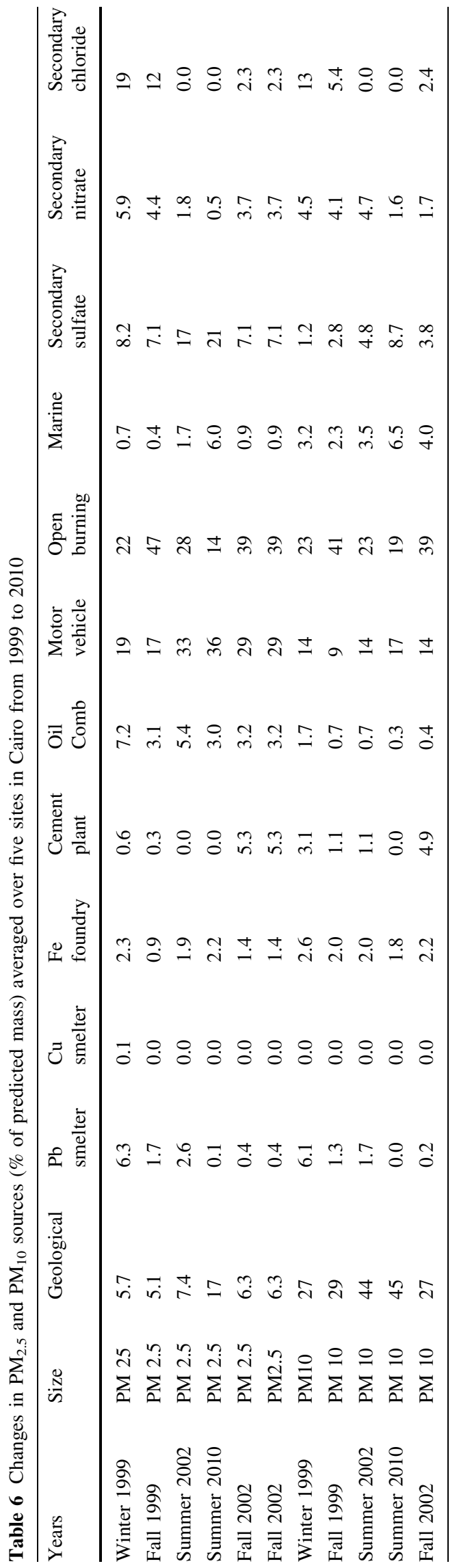

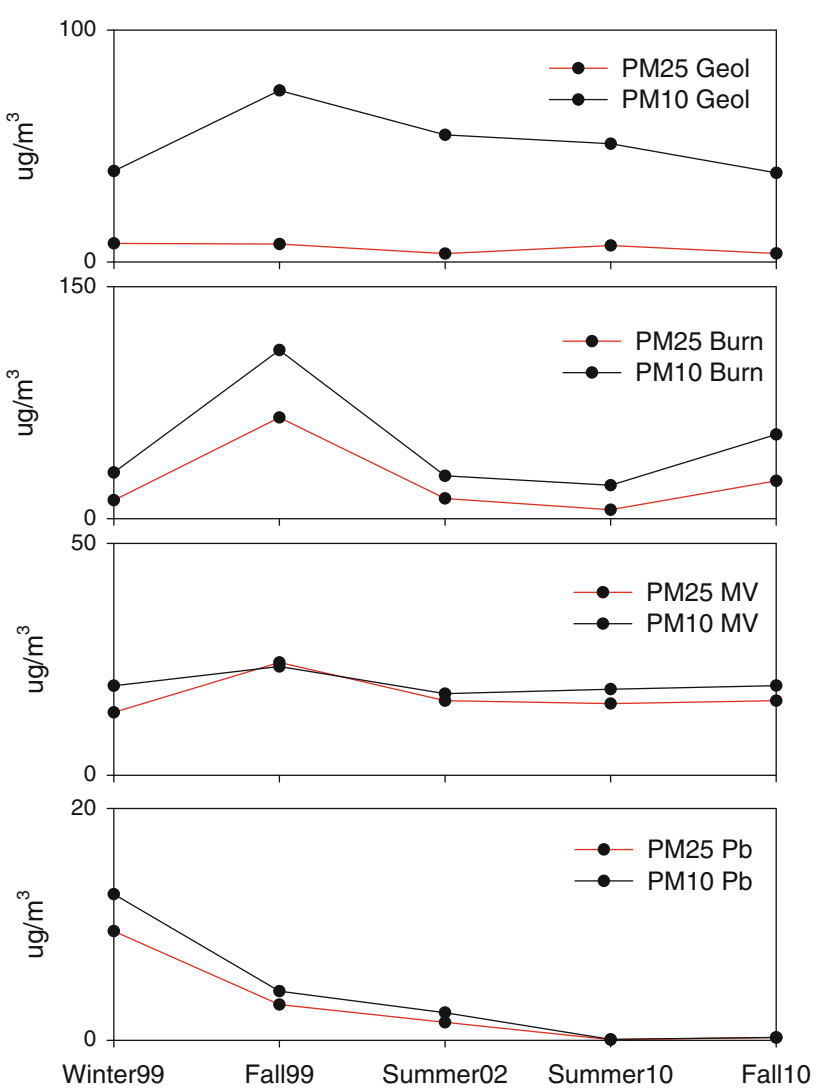

Fig. 4 Trends in $\mathrm{PM}_{2.5}$ and $\mathrm{PM}_{10}$ source contributions in Cairo

Shobra. However, there is no long-term trend, suggesting that meteorological factors determine the geological dust contribution. Lead smelter and copper smelter (foundry) contributions were a small fraction of $\mathrm{PM}_{2.5}$ at all sites except Shobra. Because of the reduction of $\mathrm{Pb}$ smelter emissions after 1999 and 2002, there were discernible decreases at the other sites as well. The iron foundry contribution in both size fraction has not changed significantly over time. The relative oil combustion (Mazot) contribution to $\mathrm{PM}_{2.5}$, decreased after winter 1999, but there was a discernible peak during the summer of 2002 at El-Qualaly, El-Zamalek, Kaha, and Shobra. This suggests a relative increase in industrial activity or power production in the summer of 2002. There has been a general increase in the motor vehicle contribution as a percent of $\mathrm{PM}_{2.5}$. In general, open (vegetative/trash) burning was the largest contributor to $\mathrm{PM}_{2.5}$. The highest percentages were found during the fall season, although the relative contributions do not appear to have changed significantly from fall 1999 to fall 2010.

Figure 4 shows time series of estimated source contributions from winter 1999 to fall 2010 for greater Cairo (averaged over the five sites). There were no apparent trends in the geological (GEOL) contributions for either the $\mathrm{PM}_{2.5}$ or $\mathrm{PM}_{10}$ size fractions, although there was a peak in 
$\mathrm{PM}_{10}$ GEOL during fall 1999 due to high geological contributions at El-Qualaly, Helwan and Shobra. There were peaks in the open (vegetative/trash) burning contributions to $\mathrm{PM}_{2.5}$ and $\mathrm{PM}_{10}$ during fall 1999 and to a lesser extent during fall 2010. This is attributed to burning of agricultural waste following the fall harvest and this persists through the present. While there was a small increase during fall 1999, the trend in motor vehicle contributions to $\mathrm{PM}_{2.5}$ and $\mathrm{PM}_{10}$ was generally flat over the past decade. By contrast, there was a clear decline in the $\mathrm{Pb}$ smelter contribution in Cairo. This was due to a relocation of $\mathrm{Pb}$ smelters, mainly in the Shobra area, outside of the city. This resulted in lower $\mathrm{Pb}$ smelter contributions at the other sites.

\section{Conclusion}

A PM monitoring and source apportionment study was conducted during June and October, 2010 at five sites in greater Cairo: El-Qualaly (mobile sources), Helwan (residential), Kaha (background), Shobra (industrial), and El-Zamalek (residential). This study demonstrates that the Cairo population continues to be exposed to high levels of air pollution. The Egyptian $24 \mathrm{~h} \mathrm{PM}_{10}$ standard of $70 \mu \mathrm{g} / \mathrm{m}^{3}$ was exceeded at all sites during 91 and $96 \%$ of the sampling periods in June and October, respectively. The major contributors to $\mathrm{PM}_{10}$ included resuspended geological dust, mobile source emissions, and open (vegetative/ trash) burning. During the fall 2010 period, the open (vegetative/trash) burning contribution exceeded that from soil and MV. This is likely due to agricultural waste burning following the fall harvest. A large fraction (65\%) of the open (vegetative/trash) burning contribution was found in the coarse $\left(\mathrm{PM}_{10}-\mathrm{PM}_{2.5}\right)$ size fraction probably because of the uncontrolled nature of the combustion. By contrast, most $(88 \%)$ of the motor vehicle contribution occurred in the $\mathrm{PM}_{2.5}$ fraction.

Long-term trends were examined by comparing the results from the summer and fall 2010 studies to those from source attribution studies we conducted in winter and fall 1999 and summer 2002. The highest $\mathrm{PM}_{2.5}$ and $\mathrm{PM}_{10}$ concentrations occurred during fall 1999. Average $\mathrm{PM}_{10}$ concentrations were lower and largely invariant before and after fall 1999. Average $\mathrm{PM}_{2.5}$ concentrations were lower and relatively constant after fall 1999 . The $\mathrm{PM}_{10}$ geological contribution averaged $51 \mu \mathrm{g} / \mathrm{m}^{3}$ over all sites and seasons. Much of this likely comes from resuspended road dust and construction activities. $\mathrm{PM}_{10}$ open (vegetative/trash) burning contributions were highest during fall 1999 and 2010 and averaged $37 \mu \mathrm{g} / \mathrm{m}^{3}$ over all sites and seasons. The $\mathrm{PM}_{10}$ motor vehicle contribution remained relatively constant over the period, averaging $19 \mu \mathrm{g} / \mathrm{m}^{3}$ over all sites and seasons. Without significant reduction of geological dust, motor vehicle, and open (vegetative/trash) burning emissions, the daily $\mathrm{PM}_{10}$ standard of $70 \mu \mathrm{g} / \mathrm{m}^{3}$ will continue to be exceeded. By contrast, $\mathrm{PM}_{10}$ lead concentrations have declined by nearly two orders of magnitude from winter 1999 to summer 2010. This reflects a highly successful policy of relocating large lead-emitting sources from the Shobra industrial area outside of the city.

Acknowledgments We wish to acknowledge the support of the World Bank Group, contract 7154499 and the efforts of Maged Hamed and Suiko Yoshijima of the World Bank and Moustafa Mourad and Mona Kamal of the Egyptian Environmental Affairs Agency. We also thank Dr. Mahmoud Abu-Allaban who contributed to the 1999 and 2002 CAIP studies.

\section{References}

Abu-Allaban M, Gertler AW, Lowenthal DH (2002) A preliminary apportionment of the sources of ambient $\mathrm{PM}_{10}, \mathrm{PM}_{2.5}$, and VOCs in Cairo. Atmos Environ 36:5549-5557

Abu-Allaban M, Lowenthal DH, Gertler AW, Labib M (2007) Sources of $\mathrm{PM}_{10}$ and $\mathrm{PM}_{2.5}$ in Cairo's ambient air. Environ Monit Assess 133:417-425

Chan CK, Yao X (2008) Air pollution in mega cities in China. Atmos Environ 42(1): 1-42

Chemonics International Inc. (1997) Cairo air improvement project, draft year 1 work plan. Report prepared for USAID/Egypt and Egyptian Environmental Affairs Agency, October 14, 1997

Chow JC, Watson JG (1999) Cross border transport and spatial variability in Mexicali and California's Imperial Valley. Atmos Environ 34:1833-1843

Chow JC, Watson JG, Lowenthal DH, Solomon PA, Magliano KL, Ziman SD, Richards LW (1992) $\mathrm{PM}_{10}$ source apportionment in California's San Joaquin Valley. Atmos Environ 26A(18): 3335-3354

Chow J, Watson J, Pritchett L, Pierson W, Frazier C, Purcell R (1993) The DRI thermal/optical carbon analysis system: description, evaluation and applications in U.S. air quality studies. Atmos Environ 27A:1185-1202

Chow JC, Watson JG, Houck JE, Pritchett LC, Rogers CF, Frazier CA, Egami RT, Ball BM (1994) A laboratory resuspension chamber to measure fugitive dust size distributions and chemical compositions. Atmos Environ 28(21):3463-3481

Chow JC, Watson JG, Edgerton SA, Vega E, Ortiz E (2002) Spatial differences in outdoor $\mathrm{PM}_{10}$ mass and aerosol composition in Mexico City. J Air Waste Manag Assoc 52:423-434

Chow JC, Watson JG, Lowenthal DH, Chen LWA, Zielinska B, Rinehart LR, Magliano KL (2007) Evaluation of organic markers for chemical mass balance source apportionment at the Fresno Supersite. Atmos Chem Phys 7:1741-1754

El-Shazly SM, Abdelmageed AM, Abdelaal A (1990) Studies on pollution in the atmosphere near the aluminum reduction plant at Nagi Hammady/Egypt. Water Air Soil Pollut 51:217-230

Favez O, Cachier H, Sciare J, Alfaro SC, El-Araby TM, Harhash MA, Abdelwahab MM (2008) Seasonality of major aerosol species and their transformations in Cairo megacity. Atmos Environ 42:1503-1516

Hindy KT (1991) Study of alluvial soil contamination with heavy metals due to air pollution in Cairo. Int $\mathrm{J}$ Environ Stud $38: 273-279$ 
Howes JE, Serre ML, Labib M, Samaha N, Sabra M, Araby H (2000) Ambient PM and lead levels in Cairo, Egypt: baseline year monitoring results. Paper 449 AWMA National Meeting, Salt Lake City

Mamane Y, Gottlieb J (1992) Nitrate formation on sea-salt and mineral particles-A single particle approach. Atmos Environ 26A: $1763-1769$

Marey HS, Gille JC, El-Askary HM, Shalaby EA, El-Raey ME (2010) Study of the formation of the "black cloud" and its dynamics over Cairo, Egypt, using MODIS and MISR sensors. J Geophys Res 115:D21206. doi:10.1029/2010JD014384

Marey HS, Gille JC, El-Askary HM, Shalaby EA, El-Raey ME (2011) Aerosol climatology over Nile Delta based on MODIS, MISR and OMI satellite data. Atmos Chem Phys Discuss 11: 10449-10484

Nasralla MM (1994) Air pollution in greater Cairo. In: Proceeding of the Italian-Egyptian study-days on the environment, Cairo, Egypt, October 9-20, 1994

Pye K (1989) Aeolian dust and dust deposits. Academic Press, San Diego, p 334

Rodes CE, Nasralla MM, Lawless PA (1996) An assessment and source apportionment of airborne particulate matter in Cairo, Egypt. Activity report No. 22, prepared for the USAID mission to Egypt under EHP activity No. 133-RCm delivery order No. 7
Sturchio N, Sultan M, Sharkaway ME, Maghraby AE, Taher A (1997) Concentration and isotopic composition of lead in urban particulate air, Cairo, Egypt 1966. Argonne National laboratory, Argonne, IL, and Center for Environmental Hazard Mitigation, Cairo University, Cairo, Egypt

Tiwari S, Chate DM, Srivastava AK, Bisht DS, Padmanabhamurty B (2012) Assessments of $\mathrm{PM}_{1}, \mathrm{PM}_{2.5}$ and $\mathrm{PM}_{10}$ concentrations in Delhi at different mean cycles. Geofizika 29:125-141

U.S. EPA (2008) SPECIATE version 4.2. U.S. environmental protection agency, Research Triangle Park, NC. http://www. epa.gov/ttn/chief/software/speciate/index.html

Vega E, Lowenthal DH, Ruiz H, Reyes E, Watson JG, Chow JC, Viana M, Querol X, Alastuey A (2009) Fine particle receptor modeling in the atmosphere of Mexico City. J Air Waste Manag Assoc 59:1417-1428

Watson JG, Cooper JA, Huntzicker JJ (1984) The effective variance weighting for least squares calculations applied to the mass balance receptor model. Atmos Environ 18:1347-1355

Watson JG, Chow JC, Lu Z, Fujita EM, Lowenthal DH, Lawson DR, Ashbaugh LL (1994) Chemical mass balance source apportionment of $\mathrm{PM}_{10}$ during the Southern California Air Quality Study. Aerosol Sci Technol 21:1-36 